\title{
Preferred Health care System of the people residing at Arpookara, Kottayam district in India: A cross-sectional Study
}

\author{
Article by Quereishi M.J. ${ }^{1}$, Puthenparambil S. ${ }^{2}$ \\ ${ }^{1}$ State Planning Manager - National Health Mission, Department of Health \& Family \\ Welfare, Government of Chhattisgarh State, India \\ ${ }^{2}$ Lecturer, University College of Medical Education, Mahatma Gandhi University, \\ Kottayam, India. \\ E-mail:drjaved4ph@gmail.com
}

\begin{abstract}
This study was designed to study about the preferred health care system of the people residing at Arpookara, Kottayam district in India. In this study investigator tried to find out the common health problems, preferred place for treatment, preferred system of medicine, main obstacles to access the better treatment and expectations from government for better health care delivery, of the study population. The populations for the study were the people residing at Arpookara, Kottayam district in India which includes 410 households with 2360 members. One hundred households (samples) from the study population were selected so that findings can be generalized for the population. Simple random technique is used for samples selection. Samples include 100 households with 456 members, out of which 243 members are males and rest 213 are females. The tool used for data collection is an interview schedule which consists of 2 Performa, Performa 1 and Performa 2. Performa 1 seeks personal details while Performa 2 seeks information about common health problems, preferred place for treatment, preferred system of medicine, main obstacles to access the better treatment and expectations from government for better health care delivery, of the study population. After the data collection its analysis is done. Members of 73 (73\%) households are preferring government hospital for treatment while private hospital, private practitioners and traditional healing centers are preferred by 19 (19\%), 6(6\%) and 2(2\%) house members respectively. In 94 (94\%) houses, Allopathic system of medicine is preferred while Ayurvedic and Homeopathy system of medicine are preferred by only 4 (4\%) and 2 (2\%) houses respectively. The major health problems of members (above age of 6 years) are Chikungunya-39 (9.51\%), Jaundice-17 (4.41\%), Typhoid-1 (0.24\%), Bronchial Asthama-1 (0.24\%), Viral fever--1 (0.24\%), Coronary heart disease-2 (0.48\%), Stroke- 3 (0.73\%) and Diabetes-1 (0.24\%). About 345 (84.14\%) members were not suffered from any disease since last year. According to 56 (56\%) households both the Service unavailability and financial problem are the main obstacles to access better treatment while 18 (18\%) households suggests that service unavailability only and rest $26(26 \%)$ households suggested that main obstacle is financial problem. for the better healthcare delivery, 44 (44\%) households expects availability of pure drinking water, regular cleaning of surroundings and primary health centre from government. About 31 (31\%) households' needs pure drinking water and rest $16(16 \%)$ households needs regular cleaning of surroundings. Rest 9 (9\%) households expects primary health center at their ward. On the basis of findings of this study, Researcher recommended his suggestions to higher healthcare administrative staff to take preventive measures for prevention and control of diseases and thus too maintain a high standard of health.
\end{abstract}

Keywords: Healthcare System; Treatment Place; Medicine System; Health Problem; Obstacle. 
South American Journal of Public Health

Volume 4, Issue 2, 2016

\section{Introduction}

The present study was under taken with the objectives to study the socioeconomic status, common health problems, preferred place for treatment, preferred system of medicine, main obstacles to access the better treatment and expectations from government for better healthcare delivery, of the people residing at Arpookara, Kottayam district in India. Socioeconomic Status (SES) is an economic \& sociological combined total measure of a person's work experience and of an individuals or family's economic \& social position relative to others, based on income, education \& occupation. When analyzing a family's SES, the household income earner's education \& occupation are examined, as well as combined income, versus with an individual, when their own attributes are assessed. There is a strong relation between socioeconomic status \& health. This co-relation suggests not only the poor who tend to be sick when everyone else is healthy but also that, there is a continual gradient from the top to the bottom socioeconomic ladder relation to status of health. This phenomenon is called Socio-Economic Status gradient or S.E.S. gradient. The gradient is a vector operation which operates on a scalar function to produce a vector whose magnitude is the maximum rate of change of the function at the point of gradient and which is pointed in the direction of that maximum rate of change. Socioeconomic status is typically broken into three categories, High SES, Middle SES \& Low SES to describe the three areas a family or an individual may fall into. When placing a family or individual into one of these categories any or all of the three variables (income, education and occupation) can be assessed. A fourth variable wealth may also be examined when determining socioeconomic status. Additionally, income, occupation \& education have shown to be strong predicators of a range of physical \& mental health problems, ranging from respiratory diseases, arthritis, coronary diseases and schizophrenia

"E-mail address: drjaved4ph@yahoo.com Mohammad Jawed Quereishi, MPH (Gold Medalist), MBA, PGDDHM, State Planning Manager - National Health Mission, Department of Health \& Family Welfare, Government of Chhattisgarh State, India

Mueller and Parcel defined SES in 1981 as "the relative position of a family or individual on a hierarchical social structure, based on their access to or control over wealth, prestige and power. More recently, SES has been defined as "a broad concept that refers to the placement of persons, families, households and census tracts or other aggregates with respect to the capacity to create or consume goods that are valued in our society." No matter how it is defined, it appears that SES, as it relates to health status/healthcare, is an attempt to capture an individual's or group's access to the basic resources required to achieve and maintain good health. Adler et al. present three pathways through which SES impacts health, which include its association with healthcare, environmental exposure, and health behavior and lifestyle. Together, these pathways are estimated to account for up to $80 \%$ of premature mortality.

Need of the study is to assess the socioeconomic and health status and to understand the health seeking behavior of the study population. High incidence of the Chikungunya cases in this area, during lasts years' outbreak also calls for a detailed study of the health status of the people. The findings and conclusion of the study plays an important role in understanding the socioeconomic status, health seeking behavior and environmental conditions of the people. The report may be help the officials of Arpookara, Kottayam district to notify the major problems of the community and to take corrective or remedial measures, preventive methods and thus to maintain a high standard of health.

\section{Research methodology}

The present study was conducted in Arpookara, Kottayam district. Kottayam is a city in the Indian state of Kerala. It is located in central Kerala. The city is an important trading center of spices and commercial crops, especially rubber. The populations for study were the people residing at Arpookara, kottayam in India which includes 410 households with 2360 members. One hundred households (samples) from the study population were selected using simple random technique. Samples include 100 households with 456 members, out of which 243 members are males and rest 213 are females. An interview schedule was used for data collection which consists 
of 2 Performa, Performa 1 \& Performa 2. Performa 1 seeks personal details while Performa 2 seeks information about (a) Common health problems (b) Preferred place for treatment (c) Preferred system of medicine (d) Main obstacles to access the better treatment (e) Expectations from the government for better healthcare delivery, of the study population. To analyze the data, collected information was classified in the light of the objectives set forth for the study. The classified data was coded, tabulated and was analyzed by using appropriate statistical (Percentage $\&$ Frequencies) units.

\section{Result and discussion}

The data (figure no. 1) depicts that the major health problems of members (above age group of 6 years) are Chikungunya-39(9.51\%), Jaundice-17 (4.41\%), Typhoid-1 (0.24\%), Bronchial Asthama-1 (0.24\%), Viral fever-1 (0.24\%), Coronary heart disease-2 (0.48\%), Stroke- 3 (0.73\%) and Diabetes-1 (0.24\%). About 345 (84.14\%) members were not suffered from any disease since last year. It is clear from table no. 1 that members of 73 (73\%) households are preferring government hospital for treatment, out of which 62(84.93\%) prefers due to accessibility and affordability both, $4(5.47 \%)$ due to affordability only, 3(4.10\%) due to good treatment, $2(2.73 \%)$ due to acceptability and rest 2(2.73\%) due to accessibility. Members of 19 (19\%) prefers private hospital while private practitioners and traditional healing centers are preferred by 6(6\%) and 2(2\%) household members respectively. In 94 (94\%) houses, Allopathic system of medicine is preferred while Ayurvedic and Homeopathy system of medicine are preferred by only 4 (4\%) and 2 (2\%) houses respectively (see figure no. 2 ).

Figure no. 3 shows that, according to 56 (56\%) households both the Service unavailability and financial problem are the main obstacles to access better treatment while 18 (18\%)households suggests that service unavailability only and rest 26 (26\%) households suggested that main obstacle is financial problem. For the better healthcare delivery, 44 (44\%) households expect availability of pure drinking water, regular cleaning of surroundings and primary health centre from government. About 31 (31\%) households' needs pure drinking water and rest 16 (16\%) households needs regular cleaning of surroundings. Rest 9 (9\%) households expects primary health center at their place for better healthcare delivery (See table 2).

\section{Conclusion}

The major health problems are chikungunya and jaundice. About health seeking behavior, Majority of households are preferring government hospital for treatment due to accessibility and affordability. Only few households prefer private hospitals and private practitioners for treatment as they think good treatment is available there. Most of the households are using allopathy medicine because they get quick relief but few members also prefer ayurvedic and homeopathy medicines for treatment. Service unavailability and financial problem are the main obstacles for people to access better treatment. For the delivery of better healthcare, people expects availability of pure drinking water, primary health center, regular cleaning of surroundings and better transport facility in their ward from government. 
South American Journal of Public Health Volume 4, Issue 2, 2016

\section{Tables and figures}

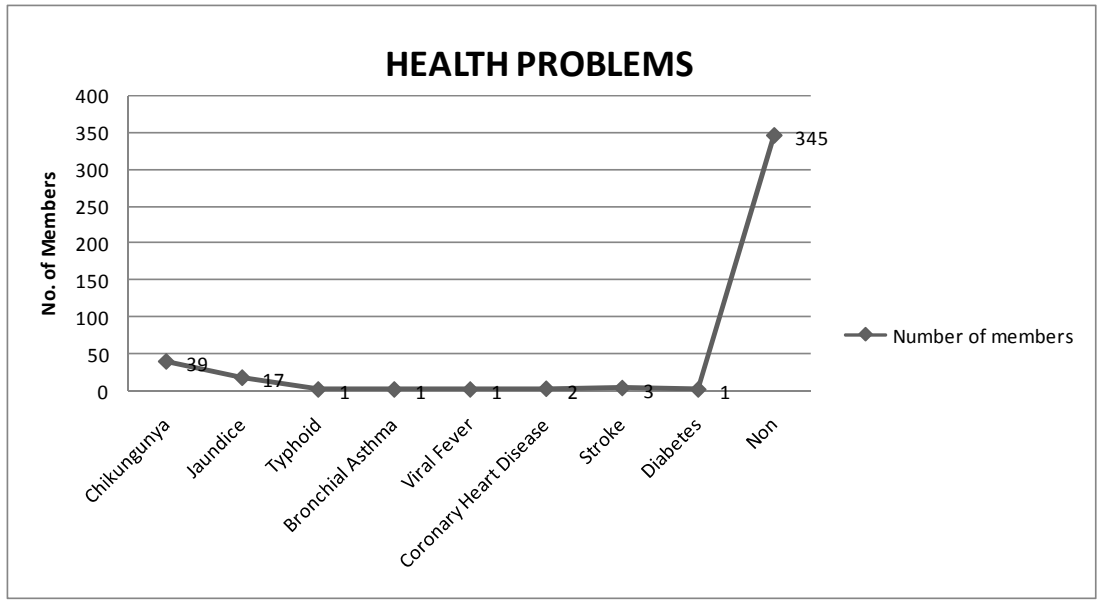

Figure No 01

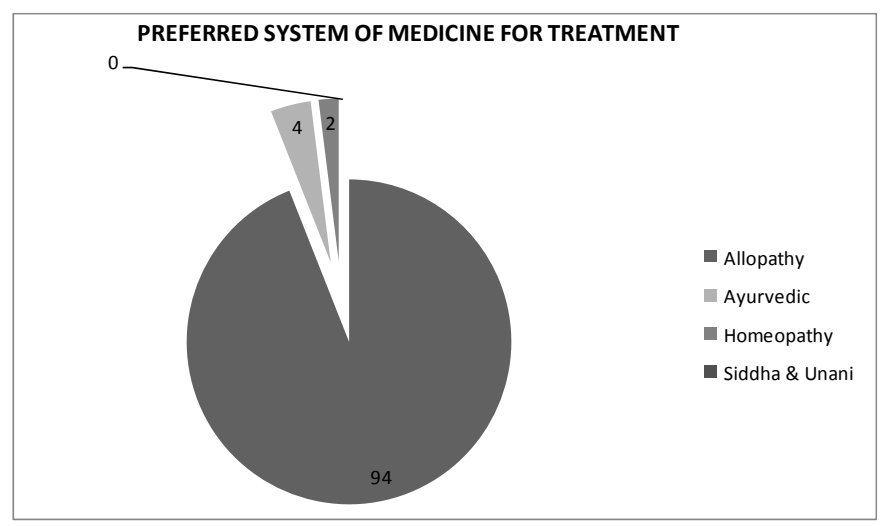

Figure No 02

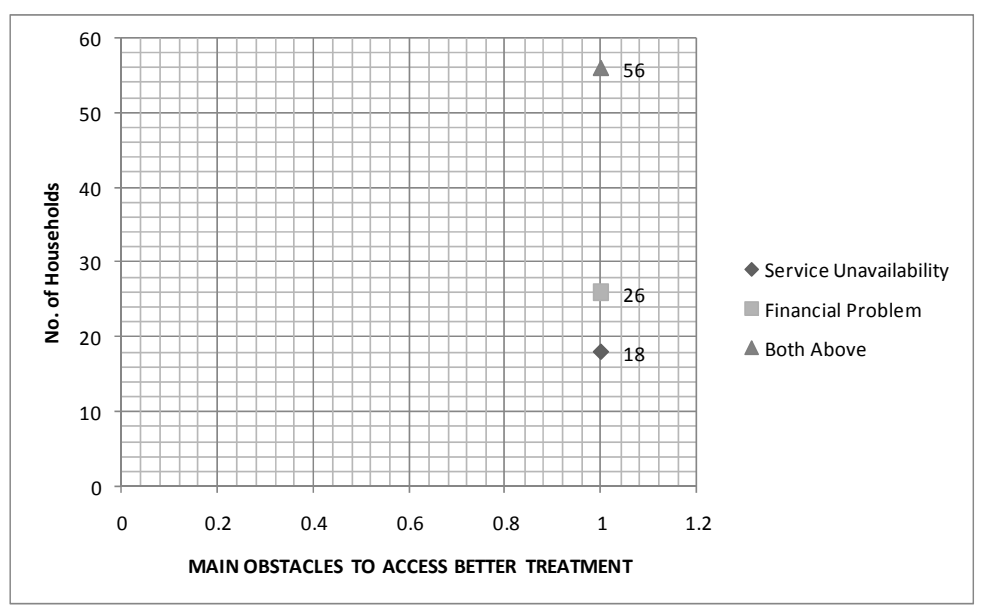

Figure No 03 
Table 1. Preferred Place for Treatment

\begin{tabular}{|l|l|l|l|l|l|l|}
\hline $\begin{array}{l}\text { Reason for } \\
\text { Preference }\end{array}$ & $\begin{array}{l}\text { Accessi } \\
\text { bility }\end{array}$ & $\begin{array}{l}\text { Acceptab } \\
\text { ility }\end{array}$ & $\begin{array}{l}\text { Affordabi } \\
\text { lity }\end{array}$ & $\begin{array}{l}\text { Good } \\
\text { Treatme } \\
\text { nt }\end{array}$ & $\begin{array}{l}\text { Accessibi } \\
\text { lity+ } \\
\text { Affordab } \\
\text { ility }\end{array}$ & $\begin{array}{l}\text { Tota } \\
\text { l }\end{array}$ \\
\hline Govt. Hospital & $\begin{array}{l}2 \\
(2.73 \%)\end{array}$ & $2(2.73 \%)$ & $4(5.47 \%)$ & $\begin{array}{l}3 \\
(4.10 \%)\end{array}$ & $\begin{array}{l}62(84.93 \\
\%)\end{array}$ & $\begin{array}{l}73 \\
(73 \% \\
)\end{array}$ \\
\hline Private Hospital & $\begin{array}{l}1 \\
(5.26 \%)\end{array}$ & $\begin{array}{l}2 \\
(10.52 \%)\end{array}$ & $1(5.26 \%)$ & $\begin{array}{l}11 \\
(57.89 \%)\end{array}$ & $\begin{array}{l}4 \\
(21.05 \%)\end{array}$ & $\begin{array}{l}19 \\
(19 \% \\
)\end{array}$ \\
\hline $\begin{array}{l}\text { Private } \\
\text { Practitioners }\end{array}$ & $\begin{array}{l}1 \\
(16.66 \%\end{array}$ & 0 & 0 & $3(50 \%)$ & $\begin{array}{l}2 \\
(33.33 \%)\end{array}$ & $\begin{array}{l}6 \\
(6 \%)\end{array}$ \\
\hline $\begin{array}{l}\text { Traditional } \\
\text { Centers }\end{array}$ & $1(50 \%)$ & $1(50 \%)$ & 0 & 0 & 0 & $\begin{array}{l}2 \\
(2 \%)\end{array}$ \\
\hline Total & 5 & 5 & 5 & 17 & 68 & 100 \\
\hline
\end{tabular}

Table 2. Expectations from Govt. for Better Healthcare Delivery

\begin{tabular}{|c|c|}
\hline Needs & Number of Households \\
\hline Pure drinking water & $31(31 \%)$ \\
\hline Regular cleaning of surrounding & $16(16 \%)$ \\
\hline Primary Health Center & $9(9 \%)$ \\
\hline All of the above & $44(44 \%)$ \\
\hline Total & $\mathbf{1 0 0}$ \\
\hline
\end{tabular}

\section{References}

[1.] Aggarwal $\mathbf{O} \mathbf{P}$ et al, A new instrument (scale) for measuring socioeconomic status of a family: Preliminary study. Indian Journal of Community Medicine, 30(4):10-12.

[2.] Archana B.Patel et al, A tool for rapid socioeconomic assessment, India Journal of Pediatrics, Volume 74-April 2007.

[3.] B.K. Mahajan, Methods in Biostatistics, 1999, Jaypee brothers Medical Publishers (P) Ltd., New Delhi.

[4.] D.Mishra, H.P.Singh, Kuppuswamy's socioeconomic status scale- a revision, India Journal of Pediatrics, 2003, 70(3): 273-274.

[5.] Dutton, Diana B, Sol Levine, Socioeconomic status and health: Overview, methodological critique and formulation, 1989, The Henry J. Kaiser Family foundation, New York.

[6.] E. Vijay, Community Medicine for paramedical students, 2002, Beacon Zen publishers, Chennai.

[7.] Frank W. Young, Socioeconomic status and health: The problem of explanation and sociological solution, 2002, Cornell University, Ithaca, New York.

[8.] Govt. of India (2001), Annual Report 2000-2001, Ministry of health and Family welfare, New Delhi.

[9.] K. Park, Park's textbook of Preventive and Social Medicine, 2007, Banarsidas Bhanot Publishers, Jabalpur.

[10.] Kuppuswamy B. Manual of socioeconomic status (Urban), 1981, Manasayan, Delhi.

[11.] L. Ramachandran, T.Dharmalingam, Health Education: A new approach, 2006, Vikash Publishing House Pvt. Ltd. Noida.

[12.] Mahajan B.K., Gupta M C, Textbook of Preventive and Social Medicine, 1995, Jaypee brothers, New Delhi.

[13.] N.Kumar et al, Kuppuswamy's Socioeconomic status scale- updating for 2007, India Journal of Pediatrics, Volume 74-December 2007.

[14.] National Family Health survey-2, 1998-1999, International Institute of population sciences, Mumbai.

[15.] P.K. Goel, A handbook of practical community medicine, 2008, Asha Deep Publications, Jammu. 
South American Journal of Public Health

Volume 4, Issue 2, 2016

[16.] P.N. Arora, Comprehensive Statistical Methods, 2007, S. Chand \& company ltd. New Delhi.

[17.] Roger et al, Oxford text book of public health, 1997, Oxford University press, Oxford, New York.

[18.] Ross, Catherine E, Chia-Ling Wu, 1995, The link Between education and health, American Sociological review 60: 719-745.

\section{Author's Profile:}

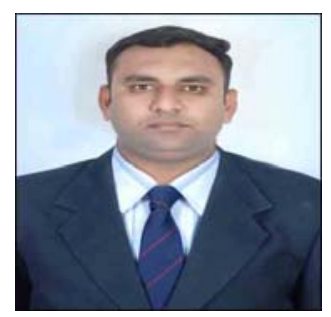

Mohammad Jawed Quereishi is rendering his services with the capacity of State Planning Manager - National Health Mission under Department of Health \& Family Welfare, Government of Chhattisgarh State in India. He is Public Health expert having a vast knowledge of Public Healthcare delivery system in India and other low-middle income countries. He has completed Master o Public Health degree with securing first rank in university merit list at University College of Medical Education, Mahatma Gandhi University, Kottayam, India. He also completed MBA in Hospital Management and PG Diploma in District Health management. He graduated in Physiotherapy from Govt. Pt. Jawaharlal Nehru Memorial Medical College, Raipur. He represented India in many international conferences. He served his services as Research Coordinator in USAID India projects and External Consultant with Futures Group International in Ranchi for the assessment of Public Health facilities and RCH camps. Previous to this he also volunteered in many Public Health programmes. 